\title{
Non-contiguous finished genome sequence and description of Sulfurimonas hongkongensis sp. nov., a strictly anaerobic de- nitrifying, hydrogen- and sulfur-oxidizing chemolithoautotroph isolated from marine sediment
}

\author{
Lin Cai ${ }^{1}$, Ming-Fei Shao ${ }^{2}$, Tong Zhang ${ }^{1 *}$ \\ ${ }^{1}$ Environmental Biotechnology Laboratory, Department of Civil Engineering, The University \\ of Hong Kong, Hong Kong SAR, China \\ ${ }^{2}$ Department of Civil and Environmental Engineering, Harbin Institute of Technology Shen- \\ zhen Graduate School, Shenzhen, China \\ * Correspondence: Tong Zhang (zhangt@hku.hk)
}

Keywords: Sulfurimonas hongkongensis, chemolithoautotroph, sulfur oxidation, denitrification, anaerobe, marine sediment, genome

\begin{abstract}
Here, we report a type strain AST-10 representing a novel species Sulfurimonas hongkongensis within Epsilonproteobacteria, which is involved in marine sedimentary sulfur oxidation and denitrification. Strain AST $-10^{\top}\left(=\right.$ DSM $\left.22096^{\top}=J C M ~ 18418^{\top}\right)$ was isolated from the coastal sediment at the Kai Tak Approach Channel connected to Victoria Harbour in Hong Kong. It grew chemolithoautotrophically using thiosulfate, sulfide or hydrogen as the sole electron donor and nitrate as the electron acceptor under anoxic conditions. It was rodshaped and grew at $15-35^{\circ} \mathrm{C}$ (optimum at $30^{\circ} \mathrm{C}$ ), $\mathrm{pH}$ 6.5-8.5 (optimum at 7.0-7.5), and 10-60 $\mathrm{g} \mathrm{L}^{-1} \mathrm{NaCl}$ (optimum at $30 \mathrm{~g} \mathrm{~L}^{-1}$ ). Genome sequencing and annotation of strain AST-10 showed a 2,302,023 bp genome size, with $34.9 \%$ GC content, 2,290 protein-coding genes, and 42 RNA genes, including 3 rRNA genes.
\end{abstract}

\section{Introduction}

The genus Sulfurimonas was formally proposed in 2003, and included only one species, Sulfurimonas autotrophica $0 \mathrm{~K} 10^{\mathrm{T}}$, at that time [1]. Since then, several novel species have been identified, such as Sulfurimonas paralvinellae $\mathrm{GO}^{\mathrm{T}} \quad$ [2], Sulfurimonas denitrificans DSM $1251^{\mathrm{T}}$ (reclassified, previously known as Thiomicrospira denitrificans) [2], and Sulfurimonas gotlandica GD1 ${ }^{\mathrm{T}}$ [3]. Here, we report another novel species, Sulfurimonas hongkongensis AST-10 ${ }^{\mathrm{T}}$, isolated from coastal sediment, and describe its features, together with the genome sequencing and annotation.

Currently, all known Sulfurimonas members were isolated from marine sediments except for strain GD1 from deep seawater [4]. The most widely shared feature of Sulfurimonas members is chemolithoautotrophy; strains can grow by oxidizing hydrogen gas, elemental sulfur, hydrogen sulfide, or thiosulfate [1-7]. In our previous studies, anoxic sulfur-oxidizing bacteria were demonstrated to dominate the nitrate induced marine sedi- ment remediation process [8-10]. Phylogenetic analysis based on 16S rRNA genes showed that Epsilonproteobacteria closely related to $S$. denitrificans constituted the major bacterial population during such remediation of the sediment at Kai Tak Approach Channel, Hong Kong, China. Strain AST-10 ${ }^{\mathrm{T}}$ was isolated from the sediment and named Sulfurimonas hongkongensis sp. nov., based on its unique physiological and phylogenetic characteristics.

\section{Classification and features}

Sediment was collected $10-50 \mathrm{~cm}$ below the seawater/sediment interface at the Kai Tak Approach Channel connected to Victoria Harbor in Hong Kong, China. Sewage and industrial effluent had been discharged there for decades until the installation of a new sewage collection system in the late 1990s. The long lasting sulfate-reducing conditions resulted in a high sulfide concentration in the sediment, where an AVS (Acid-Volatile Sulfide) of $198 \mu \mathrm{mol} \mathrm{g-1}$ had been measured [8]. The pore water after centrifugation at 4,000 rpm for $15 \mathrm{~min}$ had a pH of 7.89 and a salinity of $2.9 \%$. 
Enrichments were prepared by adding $20 \mathrm{~g}$ of wet sediment $(32.0 \%$ dry matter) to serum bottles containing $70 \mathrm{~mL}$ of sterilized seawater, purged with $\mathrm{N}_{2}$ and incubated for at least $24 \mathrm{~h}$ at room temperature. Potassium nitrate $\left(1 \mathrm{~g} \mathrm{~L}^{-1}\right)$ and sodium phosphate, monobasic $\left(0.1 \mathrm{mmol} \mathrm{L}^{-1}\right)$, were then added from sterilized stock solutions. The bottles were incubated at $28^{\circ} \mathrm{C}$ in a water bath for $72 \mathrm{~h}$. The enrichments were plated onto agar plates of DSM113-S medium, a salinity modified version of DM113 medium that is recommended by DSMZ for nitrate-reducing and sulfideoxidizing bacteria. One liter of DSM113-S contained: $\mathrm{KH}_{2} \mathrm{PO}_{4}(2.0 \mathrm{~g}), \mathrm{KNO}_{3}(4.0 \mathrm{~g}), \mathrm{NH}_{4} \mathrm{Cl}(1.0 \mathrm{~g})$, $\mathrm{MgSO}_{4} \cdot 7 \mathrm{H}_{2} \mathrm{O}\left(0.8 \mathrm{~g}\right.$ ), $\mathrm{Na}_{2} \mathrm{~S}_{2} \mathrm{O}_{3} \cdot 5 \mathrm{H}_{2} \mathrm{O}$ (5.0 g), $\mathrm{NaHCO}_{3}$ $(1.0 \mathrm{~g}), \mathrm{FeSO}_{4} \cdot 7 \mathrm{H}_{2} \mathrm{O}(2.0 \mathrm{mg}), \mathrm{NaCl}(25.0 \mathrm{~g})$ and 2 $\mathrm{ml}$ of trace element solution SL-4. Solid media contained $1.5 \%$ bacterial agar from Difco. All media were sterilized by autoclaving and cooled under $\mathrm{N}_{2}$ atmosphere. Colonies formed on plates were picked and further purified by re-streaking single colonies on agar plates for more than 20 rounds (4-10 d round ${ }^{-1}$ ). A colony isolated and purified from the above process was defined as strain AST$10^{\mathrm{T}}$.

The 16S phylogenetic tree shown in Figure 1 indicated that strain AST-10 $10^{\mathrm{T}}$ is a member of the genus Sulfurimonas, (Table 1). An online BLAST query in NCBI using the 16S rRNA gene sequence from strain AST $-1^{\mathrm{T}}$ showed a relatively low identity to all currently identified Sulfurimonas species, including S. denitrificans DSM $1251^{\mathrm{T}}$ (97\% identity), S. gotlandica GD1 ${ }^{\mathrm{T}}$ (95\% identity), S. autotrophica OK10 $10^{\mathrm{T}}$ (95\% identity), and S. paralvinellae G025 ${ }^{\mathrm{T}}$ (94\% identity). Using the commonly accepted criterion of a $97 \% 16 \mathrm{~S}$ rDNA sequence similarity cutoff for defining species $[19,20]$, strain AST-10 ${ }^{\mathrm{T}}$ could accordingly be identified as a novel species within the genus Sulfurimonas.

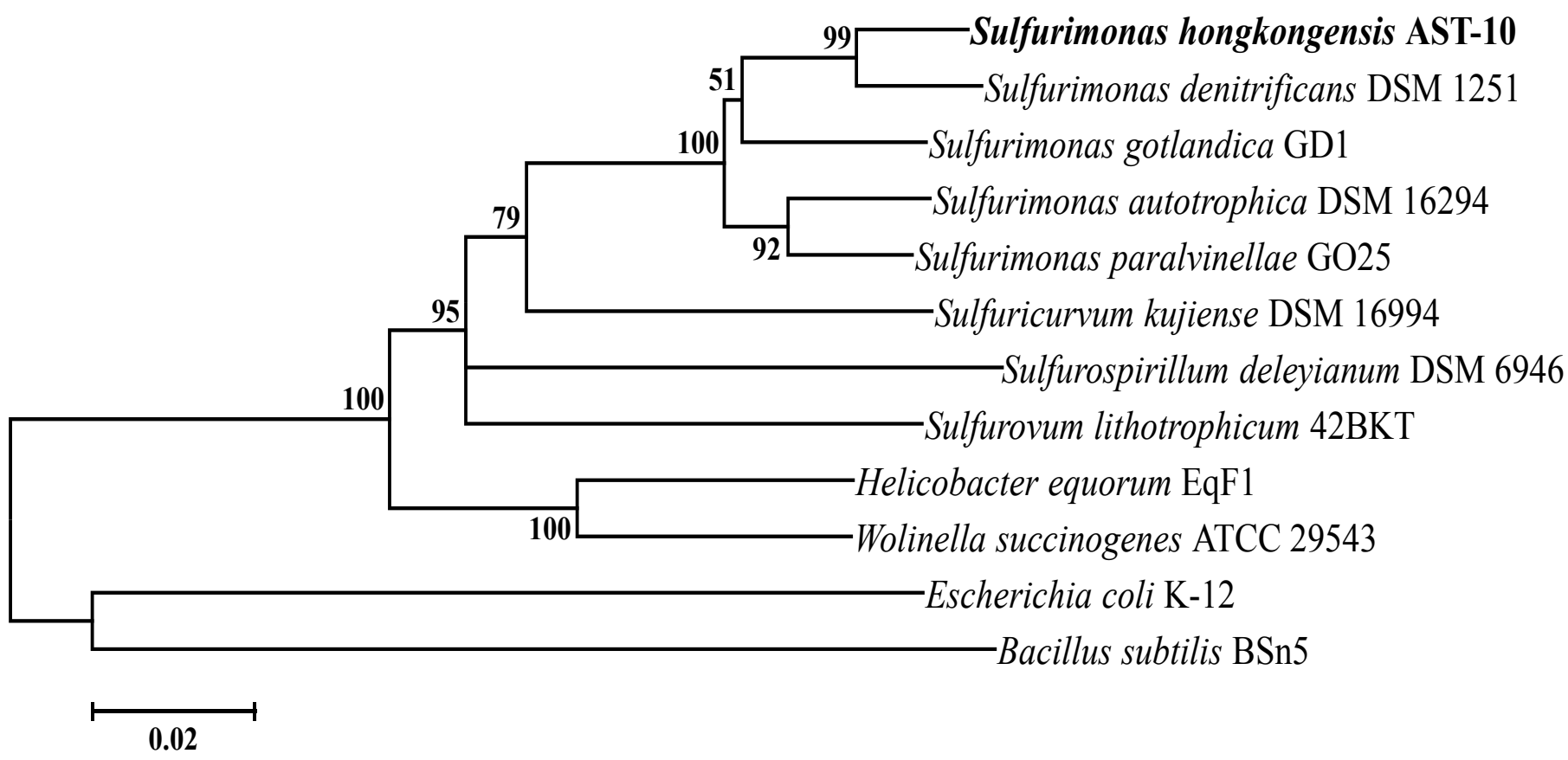

Figure 1. Phylogenetic tree highlighting the position of Sulfurimonas hongkongensis relative to the other species within the Helicobacteriaceae. The neighbor-joining tree was constructed using MEGA 5.05 and tested with 1,000 bootstrap replicates. Bootstrap values over $50 \%$ are shown and the scale bar 0.02 represents $2 \%$ nucleotide substitution. All reference sequences can be exactly searched and retrieved from NCBI GenBank based on the full name of each strain. 
Table 1. Classification and general features features of Sulfurimonas hongkongensis AST-10 based on the MIGS recommendations [11]

\begin{tabular}{|c|c|c|c|}
\hline MIGS ID & Property & Term & $\begin{array}{l}\text { Evidence } \\
\text { code }^{\mathrm{a}}\end{array}$ \\
\hline & Current classification & Domain Bacteria & TAS [12] \\
\hline & & Phylum Proteobacteria & TAS [13] \\
\hline & & Class Epsilonproteobacteria & $\begin{array}{l}\text { TAS } \\
{[14,15]}\end{array}$ \\
\hline & & Order Campylobacterales & $\begin{array}{l}\text { TAS } \\
{[14,16]}\end{array}$ \\
\hline & & Family Helicobacteraceae & \\
\hline & & Genus Sulfurimonas & $\begin{array}{l}{[14,17]} \\
\text { TAS [1-3] }\end{array}$ \\
\hline & & Species Sulfurimonas hongkongensis & IDA \\
\hline & & Type strain AST-10 & IDA \\
\hline & Gram stain & Gram-negative & TAS [1] \\
\hline & Cell shape & Rod-shaped, 0.2-0.4 $\mu \mathrm{m} \times 0.5-1.2 \mu \mathrm{m}$ & IDA \\
\hline & Motility & Not reported & \\
\hline & Sporulation & No & NAS \\
\hline & Temperature range & $15-35^{\circ} \mathrm{C}$ & IDA \\
\hline & Optimum temperature & $30^{\circ} \mathrm{C}$ & IDA \\
\hline & Carbon source & $\mathrm{HCO}_{3}^{-}, \mathrm{CO}_{2}$ & IDA \\
\hline & Energy source & $\mathrm{H}_{2}, \mathrm{HS}^{-}$or $\mathrm{S}_{2} \mathrm{O}_{3}{ }^{2-}$ & IDA \\
\hline & Terminal electron receptor & $\mathrm{NO}_{3}^{-}$ & IDA \\
\hline MIGS-6 & Habitat & Coastal sediment & IDA \\
\hline MIGS-6.3 & Salinity & $10-60 \mathrm{~g} \mathrm{~L}^{-1} \mathrm{NaCl}$, optimum at $30 \mathrm{~g} \mathrm{~L}^{-1}$ & IDA \\
\hline MIGS-22 & Oxygen & Strict anaerobe & IDA \\
\hline MIGS-15 & Biotic relationship & Free living & IDA \\
\hline MIGS-14 & Pathogenicity & Not reported as a pathogen & NAS \\
\hline MIGS-4 & Geographic location & Kai Tak Approach Channel, Hong Kong & IDA \\
\hline MIGS-5 & Sample collection time & July, 2006 & IDA \\
\hline $\begin{array}{l}\text { MIGS-4.1 } \\
\text { MIGS-4.2 }\end{array}$ & Latitude - Longitude & $22.33^{\circ} \mathrm{N}-114.19^{\circ} \mathrm{E}$ & TAS \\
\hline MIGS-4.3 & Depth & $10-50 \mathrm{~cm}$ depth of coastal sediment & IDA \\
\hline MIGS-4.4 & Altitude & below sea surface & IDA \\
\hline
\end{tabular}

aEvidence codes - IDA: Inferred from Direct Assay; TAS: Traceable Author Statement (i.e., a direct report exists in the literature); NAS: Non-traceable Author Statement (i.e., not directly observed for the living, isolated sample, but based on a generally accepted property for the species, or anecdotal evidence). These evidence codes are from the Gene Ontology project [18].

Cell morphology was examined by Scanning Electron Microscopy (SEM). As shown in Figure 2, the cells of AST-10 ${ }^{\mathrm{T}}$ were rod-shaped, 0.2-0.4 $\mu \mathrm{m}$ in diameter, and 0.5-1.2 $\mu \mathrm{m}$ in length. On solid medi- um, AST-10 $10^{\mathrm{T}}$ grew and formed small, white, transparent, round shaped colonies with smooth boundaries. 


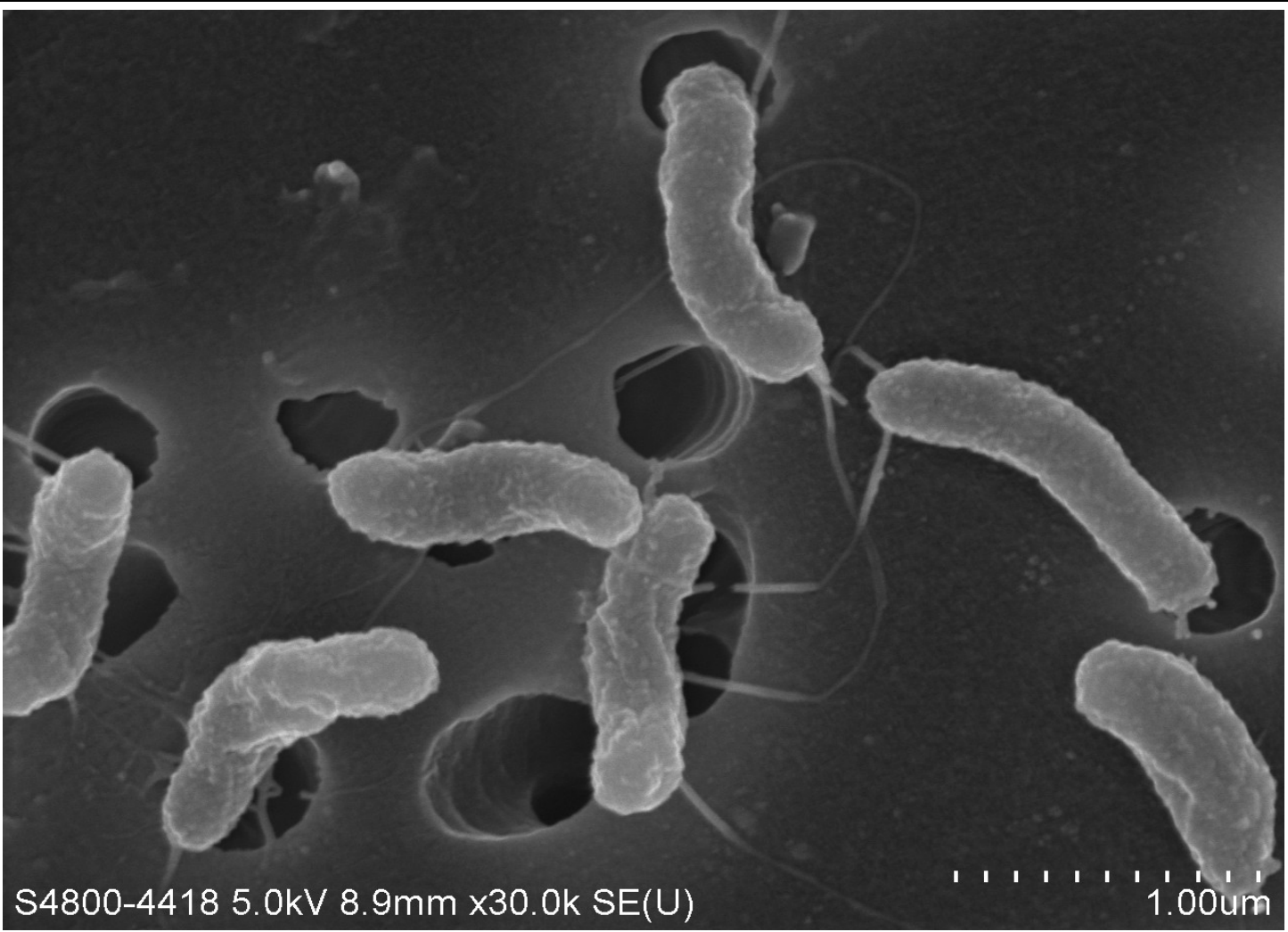

Figure 2. Scanning electron micrograph of Sulfurimonas hongkongensis AST-10 ${ }^{\top}$. The scale bar represents 1.0 $\mu \mathrm{m}$.

\section{Physiology}

Effects of temperature, $\mathrm{pH}$, and salinity on the growth of strain AST-10 $10^{\mathrm{T}}$ were investigated, showing that it grew at $15-35^{\circ} \mathrm{C}$ (optimum at $30^{\circ} \mathrm{C}$ ), $\mathrm{pH}$ 6.5-8.5 (optimum at 7.0-7.5), and 10-60 $\mathrm{g} \mathrm{L}^{-1} \mathrm{NaCl}$ (optimum at $30 \mathrm{~g} \mathrm{~L}^{-1}$ ). The generation time of strain AST-10T under optimal conditions was tested as $6.1 \mathrm{~h}$. It was significantly shorter than other species, such as $S$. paralvinellae $\mathrm{GO}^{\mathrm{T}} 5^{\mathrm{T}}$ and $S$. denitrificans DSM $1251^{\mathrm{T}}$. The cell yield of strain AST- $10^{\mathrm{T}}$ was $5.2 \mathrm{~g}$ dry weight per mole of $\mathrm{S}_{2} \mathrm{O}_{3}{ }^{2-}$. This value is similar to that of its Epsilonproteobacterial relative $S$. denitrificans DSM $1251^{\mathrm{T}}$ (5.72 g), but only about one-half of the Betaproteobacterial Thiobacillus denitrificans $(11.6 \mathrm{~g})$. Such difference in growth efficiency might be attributed to the different pathways used for carbon fixation and metabolism.

To determine whether electron acceptors other than $\mathrm{NO}_{3}-$ would sustain the growth of strain AST$10^{\mathrm{T}}, \mathrm{SO}_{4}^{2-}, \mathrm{NO}_{2}-\mathrm{Fe}^{3+}$, and $\mathrm{O}_{2}$ were separately tested with $\mathrm{S}_{2} \mathrm{O}_{3}{ }^{2-}$ as the sole electron donor. No growth was observed using any of these electron acceptors. $\mathrm{S}_{2} \mathrm{O}_{3}{ }^{2-}, \mathrm{HS}$, and $\mathrm{H}_{2}$ can support the growth of strain AST-10 $10^{\mathrm{T}}$ as electron donors, however, acetate, lactate, malate, formate, pyruvate, glucose, glycerol, and yeast extract cannot. Hence, strain AST $-10^{\mathrm{T}}$ was a chemolithoautotroph, using $\mathrm{NO}_{3}{ }^{-}$as an electron acceptor and $\mathrm{S}_{2} \mathrm{O}_{3}{ }^{2-}$, HS- or $\mathrm{H}_{2}$ as an electron donor. The time course of $\mathrm{S}_{2} \mathrm{O}_{3}{ }^{2-}$ oxidation and $\mathrm{NO}_{3}-$ reduction during strain AST-10 growth was monitored. $\mathrm{N}_{2}$ was the dominant denitrification product, no accumulation of $\mathrm{N}_{2} \mathrm{O}$ and $\mathrm{NO}_{2}$ - was detected, when it was cultivated using DSM113-S at $30^{\circ} \mathrm{C}$ and pH 7.5. Significant production of insoluble $\mathrm{S}^{0}$ occurred when it was cultured with an excess amount of $\mathrm{S}_{2} \mathrm{O}_{3}{ }^{2-}$ (molar ratio of $\mathrm{S}_{2} \mathrm{O}_{3}{ }^{2-} / \mathrm{NO}_{3}^{-}>2$ ). $\mathrm{SO}_{4}^{2-}$ became the dominant oxidation product under excess $\mathrm{NO}_{3}$ - conditions (molar ratio of $\mathrm{S}_{2} \mathrm{O}_{3}^{2-} / \mathrm{NO}_{3}^{-}<0.25$ ). This was quite similar to the well-characterized strain Thiomicrospira CVO [21]. But for S. denitrificans DSM 1251 ${ }^{\mathrm{T}}$, no accumulation of insoluble $\mathrm{S}^{0}$ was observed even under a high molar ratio of $\mathrm{S}_{2} \mathrm{O}_{3}{ }^{2-}$ $/ \mathrm{NO}_{3}^{-}$[5].

\section{Chemotaxonomy}

Cellular fatty acid composition was analyzed using the cells grown in DSM113-S medium at $30^{\circ} \mathrm{C}$ in the late-exponential phase. The major cellular fatty acids of strain AST-10 $10^{\mathrm{T}}$ were $\mathrm{C}_{14: 0}(4.8 \%), \mathrm{C}_{16: 0}$ (32.8\%), 2-OH $\mathrm{C}_{16: 0}$ (9.5\%), $\mathrm{C}_{16: 1}(14.6 \%), \mathrm{C}_{18: 0}$ (16.9\%), and $\mathrm{C}_{18: 1}(19.2 \%)$. This composition was 
generally similar to those of $S$. paralvinellae $\mathrm{GO} 25^{\mathrm{T}}$ and S. autotrophica $\mathrm{OK}^{\mathrm{T}}{ }^{\mathrm{T}}$. However, 2-OH $\mathrm{C}_{16: 0}$ was a unique fatty acid, differentiating AST-10 $10^{\mathrm{T}}$ from other species within the genus of Sulfurimonas.

\section{Genome sequencing and annotation}

\section{Genome project history}

The strain was selected for genome sequencing on the basis of its $16 \mathrm{~S}$ rRNA gene-based phylogenetic position within the genus Sulfurimonas (Table 1). It is the first sequenced genome of Sulfurimonas hongkongensis sp. nov. A summary of the genome sequencing project information is shown in Table 2. The genome consists of 28 contigs, which has been deposited at DDBJ/EMBL/GenBank under accession number AUPZ00000000. The version described in the present study is the first version.

Table 2. Genome sequencing project information

\begin{tabular}{lll}
\hline MIGS ID & Property & Term \\
\hline MIGS-31 & Finishing quality & High-quality draft \\
MIGS-28 & Libraries used & Paired-end 500 bp shotgun library \\
MIGS-29 & Sequencing platforms & Illumina HiSeq 2000 \\
MIGS-31.2 & Fold coverage & $3,011 \times$ \\
MIGS-30 & Assemblers & CLC Genomics Workbench 6.0.2 \\
MIGS-32 & Gene calling method & GeneMarkS+ \\
& Genbank ID & AUPZ00000000 \\
& Genbank date of re- & August 13, 2013 \\
& lease & Ecology and Evolution \\
& Project relevance & Ecolo
\end{tabular}

\section{Growth conditions and DNA isolation}

As described above, the strain was grown in DSM113-S medium under anoxic condition with optimal growth at $30^{\circ} \mathrm{C}, \mathrm{pH} 7.0-7.5$, and $\mathrm{NaCl} 30 \mathrm{~g}$ $\mathrm{L}^{-1}$. The genomic DNA used for shotgun sequencing was prepared by DSMZ.

\section{Genome sequencing and assembly}

The genome shotgun sequencing project was finished by BGI (Beijing Genomics Institute). Briefly, DNA was first mechanically fragmented with an enrichment size of $\sim 500 \mathrm{bp}$. Then the DNA fragmentation was gel purified and quality checked. The recycled DNA was used for shotgun library construction, which was finally sequenced on an Illumina HiSeq 2000 platform using the pairedend $150 \mathrm{bp}$ sequencing strategy.

A total of 6,932,096,700 bp of raw sequence was obtained, which was assembled with CLC Genomics Workbench 6.0.2 using a word size of 40 bp. The draft genome was finally assembled into 28 contigs with a 2,302,023 bp genome size and more than 3,000 fold genome coverage (Table 3).

\section{Genome annotation}

The draft genome was annotated by NCBI Prokaryotic Genome Annotation Pipeline (PGAP). Protein-coding genes with function prediction were calculated based on the PGAP result. The COGs (Clusters of Orthologous Groups) functional annotation was conducted by PRSBLAST search against COGs database with an E-value cutoff $1 \mathrm{e}-10$ $[22,23]$. Pfam domains were annotated using HMMER 3.0 program on Pfam database with an Evalue cutoff $1 \mathrm{e}-10[24,25]$. SignalP 4.1 Server was employed to analyze proteins with signal peptide [26]. TMHMM Server 2.0 was used to predict transmembrane helices in proteins [27].

\section{Genome properties}

The draft genome of Sulfurimonas hongkongensis AST $-10^{\mathrm{T}}$ was assembled into 28 contigs with a total size of 2,302,023 bp and a GC content of 34.9\%. 2,332 genes were annotated, 2,290 of which were protein-coding genes. The remaining 42 genes were RNA genes including 3 rRNA genes. A total of 1,146 of the protein-coding genes were assigned putative functions. The remaining 1,144 protein- 
teins. The AST $-10^{\mathrm{T}}$ genome properties and statis

Table 3. Nucleotide content and gene count levels of the genome

\begin{tabular}{lrr}
\hline Attribute & Value & \% $^{\text {of total }} \mathbf{~}^{\mathbf{a}}$ \\
\hline Genome size (bp) & $2,302,023$ & $100 \%$ \\
DNA coding region (bp) & $2,127,855$ & $92.4 \%$ \\
DNA G+C content (bp) & 803,203 & $34.9 \%$ \\
Number of contigs & 28 & \\
Contig N50 (bp) & 235,215 & \\
Total genes & 2332 & $100 \%$ \\
RNA genes & 42 & $1.8 \%$ \\
rRNA genes & 3 & $0.1 \%$ \\
tRNA genes & 39 & $1.7 \%$ \\
Protein-coding genes & 2290 & $98.2 \%$ \\
Pseudo genes & 0 & $0.0 \%$ \\
Frameshifted genes & 0 & \\
Protein-coding genes with function prediction & 1146 & $50.0 \%$ \\
Protein-coding genes assigned to COGs & 1700 & $74.2 \%$ \\
Protein-coding genes assigned Pfam domains & 1516 & $66.2 \%$ \\
Protein-coding genes with signal peptides & 155 & $6.8 \%$ \\
Protein-coding genes with transmembrane helices & 565 & $24.7 \%$ \\
\hline
\end{tabular}

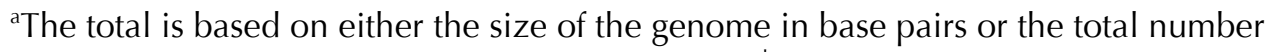
of protein coding genes in the annotated genome, ${ }^{\mathrm{b}} \mathrm{Also}$ includes 54 pseudogenes and 5 other genes.

Table 4. Number of genes associated with the 25 general COG functional categories

\begin{tabular}{llll}
\hline Code & Value & \%age $^{\mathbf{a}}$ & Description \\
\hline J & 130 & 5.7 & Translation \\
A & 0 & 0.0 & RNA processing and modification \\
K & 64 & 2.8 & Transcription \\
L & 89 & 3.9 & Replication, recombination and repair \\
B & 0 & 0.0 & Chromatin structure and dynamics \\
D & 16 & 0.7 & Cell cycle control, mitosis and meiosis \\
Y & 0 & 0.0 & Nuclear structure \\
V & 27 & 1.2 & Defense mechanisms \\
T & 163 & 7.1 & Signal transduction mechanisms \\
M & 138 & 6.0 & Cell wall/membrane biogenesis \\
N & 68 & 3.0 & Cell motility \\
Z & 0 & 0.0 & Cytoskeleton \\
W & 0 & 0.0 & Extracellular structures \\
U & 58 & 2.5 & Intracellular trafficking and secretion \\
O & 69 & 3.0 & Posttranslational modification, protein turnover, chaperones \\
C & 128 & 5.6 & Energy production and conversion \\
G & 52 & 2.3 & Carbohydrate transport and metabolism \\
E & 134 & 5.9 & Amino acid transport and metabolism \\
F & 55 & 2.4 & Nucleotide transport and metabolism \\
H & 97 & 4.2 & Coenzyme transport and metabolism \\
I & 42 & 1.8 & Lipid transport and metabolism \\
P & 101 & 4.4 & Inorganic ion transport and metabolism \\
Q & 17 & 0.7 & Secondary metabolites biosynthesis, transport and catabolism \\
R & 158 & 6.9 & General function prediction only \\
S & 94 & 4.1 & Function unknown \\
- & 590 & 25.8 & Not in COGs \\
\hline a & The total is based on the total number of protein coding genes in the annotated genome.
\end{tabular}




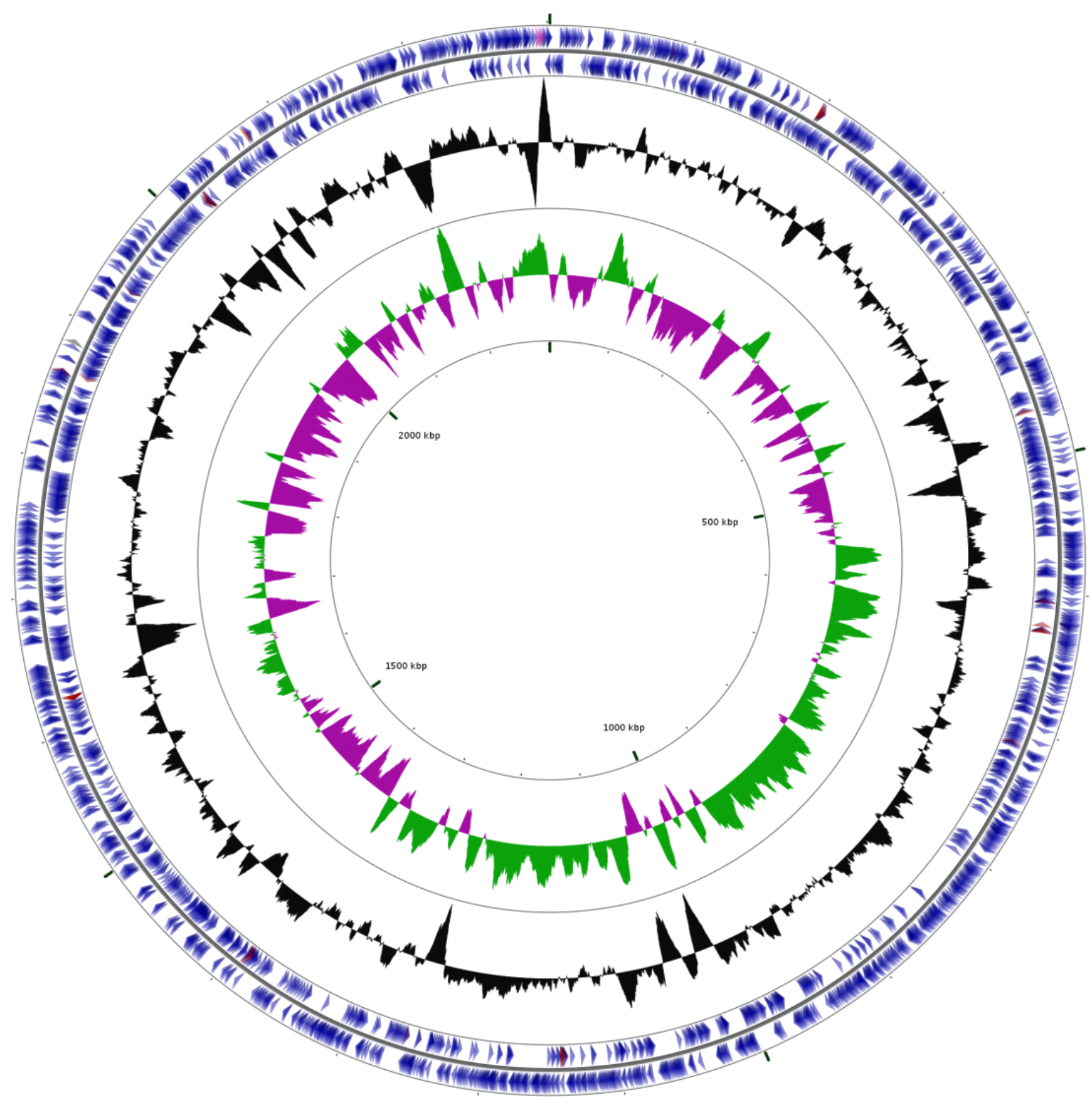

Figure 3. Graphical circular map of the Sulfurimonas hongkongensis AST-10 genome. Seen from the outside to the inside: genes on forward strand, genes on reverse strand, GC content, GC skew. The graphical map was plotted on the CGview Server.

\section{Conclusion}

\section{Description of Sulfurimonas hongkongensis}

\section{sp. nov.}

Sulfurimonas hongkongensis (hong.kong.en'sis. N.L. fem. adj. hongkongensis pertaining to Hong Kong, the city where the type strain was isolated). Strain AST $-10^{\mathrm{T}}$ is rod-shaped with size of 0.2-0.4 $\mu \mathrm{m} \times 0.5-1.2 \mu \mathrm{m}$. It is an obligate anaerobe and occurs singly. The temperature range for growth is $15-35^{\circ} \mathrm{C}$, optimum at $30^{\circ} \mathrm{C}$. The $\mathrm{pH}$ range for growth is 6.5-8.5, optimum at 7.0-7.5. The salinity range for growth is $10-60 \mathrm{~g} \mathrm{~L}^{-1}$, and optimum at 30 $\mathrm{g} \mathrm{L}^{-1}$. Strictly chemolithoautotrophic growth occurs with $\mathrm{H}_{2}$, HS- or $\mathrm{S}_{2} \mathrm{O}_{3}{ }^{2-}$ as an electron donor and with nitrate as an electron acceptor. Nitrate is reduced to $\mathrm{N}_{2}$, and reduced sulfur compounds are oxidized into $\mathrm{S}^{0}$ or $\mathrm{SO}_{4}{ }^{2-}$ (depending on molar ratio of $\mathrm{S}_{2} \mathrm{O}_{3}{ }^{2-} / \mathrm{NO}_{3}{ }^{-}$). The major cellular fatty acids are $\mathrm{C}_{14: 0}, \mathrm{C}_{16: 0}, 2-\mathrm{OH} \mathrm{C}_{16: 0}, \mathrm{C}_{16: 1}, \mathrm{C}_{18: 0}$, and $\mathrm{C}_{18: 1}$, with $\mathrm{C}_{16: 0}$ 2-OH as a unique fatty acid different from other species in the genus Sulfurimonas. 
The type strain AST-10 $10^{\mathrm{T}}=\mathrm{DSM} 2096^{\mathrm{T}}=\mathrm{JCM}$ $18418^{\mathrm{T}}$, was isolated from coastal sediment at the Kai Tak Approach Channel connected to Victoria Harbour in Hong Kong, China. The GC content of the genome is $34.9 \%$. The genome sequence has been deposited at DDBJ/EMBL/GenBank under accession number AUPZ00000000.

\section{Acknowledgments}

Dr. Lin Cai thanks The University of Hong Kong for the Postdoctoral Fellowship. This study was financially supported by the Research Grants Council of Hong Kong (HKU7201/11E).

\section{References}

1. Inagaki F, Takai K, Kobayashi H, Nealson KH, Horikoshi K. Sulfurimonas autotrophica gen. nov., sp. nov., a novel sulfur-oxidizing epsilonproteobacterium isolated from hydrothermal sediments in the Mid-Okinawa Trough. Int J Syst Evol Microbiol 2003; 53:1801-1805. PubMed http://dx.doi.org/10.1099/ijs.0.02682-0

2. Takai K, Suzuki M, Nakagawa S, Miyazaki M, Suzuki Y, Inagaki F, Horikoshi K. Sulfurimonas paralvinellae sp. nov., a novel mesophilic, hydrogen- and sulfur-oxidizing chemolithoautotroph within the Epsilonproteobacteria isolated from a deep-sea hydrothermal vent polychaete nest, reclassification of Thiomicrospira denitrificans as Sulfurimonas denitrificans comb. nov. and emended description of the genus Sulfurimonas. Int J Syst Evol Microbiol 2006; 56:1725-1733. PubMed http://dx.doi.org/10.1099/ijs.0.64255-0

3. Labrenz M, Grote J, Mammitzsch K, Boschker HT, Laue M, Jost G, Glaubitz S, Jurgens K.

Sulfurimonas gotlandica sp. nov., a chemoautotrophic and psychrotolerant epsilonproteobacterium isolated from a pelagic Baltic Sea redoxcline, and an emended description of the genus Sulfurimonas. Int I Syst Evol Microbiol 2013; 63:4141-4148. PubMed http://dx.doi.org/10.1099/ijs.0.048827-0

4. Grote J, Schott T, Bruckner CG, Glockner FO, Jost G, Teeling H, Labrenz M, Jurgens K. Genome and physiology of a model Epsilonproteobacterium responsible for sulfide detoxification in marine oxygen depletion zones. Proc Natl Acad Sci USA 2012; 109:506-510. PubMed http://dx.doi.org/10.1073/pnas.1111262109

5. Sievert SM, Scott KM, Klotz MG, Chain PS, Hauser LJ, Hemp J, Hugler M, Land M, Lapidus A, Larimer FW, et al. Genome of the epsilonproteobacterial chemolithoautotroph Sulfurimonas denitrificans. Appl Environ Microbiol
2008; 74:1145-1156. PubMed

http://dx.doi.org/10.1128/AEM.01844-07

6. Sikorski J, Munk C, Lapidus A, Ngatchou Djao OD, Lucas S, Glavina Del Rio T, Nolan M, Tice $\mathrm{H}$, Han C, Cheng JF, et al. Complete genome sequence of Sulfurimonas autotrophica type strain (OK10). Stand Genomic Sci 2010; 3:194-202. PubMed

7. Bruckner CG, Mammitzsch K, Jost G, Wendt J, Labrenz M, Jurgens K. Chemolithoautotrophic denitrification of Epsilonproteobacteria in marine pelagic redox gradients. Environ Microbiol 2013; 15:1505-1513. PubMed http://dx.doi.org/10.1111/j.14622920.2012.02880.x

8. Shao M, Zhang T, Fang $\mathrm{HH}$. Autotrophic denitrification and its effect on metal speciation during marine sediment remediation. Water Res 2009; 43:2961-2968. PubMed http://dx.doi.org/10.1016/j.watres.2009.04.016

9. Zhang M, Zhang T, Shao MF, Fang HH. Autotrophic denitrification in nitrate-induced marine sediment remediation and Sulfurimonas denitrificans-like bacteria. Chemosphere 2009; 76:677-682. PubMed http://dx.doi.org/10.1016/j.chemosphere.2009.03. $\underline{066}$

10. Shao MF, Zhang T, Fang HH, Li X. The effect of nitrate concentration on sulfide-driven autotrophic denitrification in marine sediment. Chemosphere $2011 ; \mathbf{8 3}: 1-6$. PubMed http://dx.doi.org/10.1016/j.chemosphere.2011.01. $\underline{042}$

11. Field D, Garrity G, Gray T, Morrison N, Selengut J, Sterk P, Tatusova T, Thomson N, Allen MJ, Angiuoli SV, et al. The minimum information about a genome sequence (MIGS) specification. Nat Biotechnol 2008; 26:541-547. PubMed http://dx.doi.org/10.1038/nbt1360

12. Woese CR, Kandler O, Wheelis ML. Towards a natural system of organisms: proposal for the domains Archaea, Bacteria, and Eucarya. Proc Natl Acad Sci USA 1990; 87:4576-4579. PubMed http://dx.doi.org/10.1073/pnas.87.12.4576

13. Garrity GM, Bell JA, Lilburn T. Phylum XIV. Proteobacteria phyl. nov. In: Garrity GM, Brenner DJ, Krieg NR, Staley JT (eds), Bergey's Manual of Systematic Bacteriology, Second Edition, Volume 2, Part B, Springer, New York, 2005, p. 1.

14. Validation List No. 107. List of new names and new combinations previously effectively, but not validly, published. Int / Syst Evol Microbiol 2006; 56:1-6. PubMed http://dx.doi.org/10.1099/ijs.0.64188-0

15. Garrity GM, Bell JA, Lilburn T. Class V. Epsilonproteobacteria class. nov. In: Garrity GM, 
Brenner DJ, Krieg NR, Staley JT (eds), Bergey's Manual of Systematic Bacteriology, Second Edition, Volume 2, Part C, Springer, New York, 2005, p. 1145.

16. Garrity GM, Bell JA, Lilburn T. Order I. Campylobacterales ord. nov. In: Garrity GM, Brenner DJ, Krieg NR, Staley JT (eds), Bergey's Manual of Systematic Bacteriology, Second Edition, Volume 2, Part C, Springer, New York, 2005, p. 1145.

17. Garrity GM, Bell JA, Lilburn T. Family II. Helicobacteraceae fam. nov. In: Garrity GM, Brenner DJ, Krieg NR, Staley JT (eds), Bergey's Manual of Systematic Bacteriology, Second Edition, Volume 2, Part C, Springer, New York, 2005, p. 1168.

18. Ashburner M, Ball CA, Blake JA, Botstein D, Butler $\mathrm{H}$, Cherry JM, Davis AP, Dolinski K, Dwight SS, Eppig JT, et al. Gene ontology: tool for the unification of biology. Nat Genet 2000; 25:25-29. PubMed http://dx.doi.org/10.1038/75556

19. Stackebrandt E, Goebel BM. A Place for DNADNA Reassociation and 16s Ribosomal-RNA Sequence-Analysis in the Present Species Definition in Bacteriology. Int J Syst Bacteriol 1994; 44:846849. http://dx.doi.org/10.1099/00207713-44-4$\underline{846}$

20. RossellóoMora R. Amann R. The species concept for prokaryotes. FEMS Microbiol Rev 2001; 25:3967. PubMed http://dx.doi.org/10.1016/S01686445(00)00040-1

21. Gevertz D, Telang AJ, Voordouw G, Jenneman GE. Isolation and characterization of strains CVO and FWKO B, two novel nitrate-reducing, sulfideoxidizing bacteria isolated from oil field brine.
Appl Environ Microbiol 2000; 66:2491-2501.

PubMed

http://dx.doi.org/10.1128/AEM.66.6.24912501.2000

22. Tatusov RL, Galperin MY, Natale DA, Koonin EV. The COG database: a tool for genome-scale analysis of protein functions and evolution. Nucleic Acids Res 2000; 28:33-36. PubMed http://dx.doi.org/10.1093/nar/28.1.33

23. Wu S, Zhu Z, Fu L, Niu B, Li W. WebMGA: a customizable web server for fast metagenomic sequence analysis. BMC Genomics 2011; 12:444. PubMed http://dx.doi.org/10.1186/1471-2164-12$\underline{444}$

24. Finn RD, Clements J, Eddy SR. HMMER web server: interactive sequence similarity searching. $\mathrm{Nu}$ cleic Acids Res 2011; 39:W29-W37. PubMed http://dx.doi.org/10.1093/nar/gkr367

25. Punta M, Coggill PC, Eberhardt RY, Mistry J, Tate J, Boursnell C, Pang N, Forslund K, Ceric G, Clements J, et al. The Pfam protein families database. Nucleic Acids Res 2012; 40:D290-D301. PubMed http://dx.doi.org/10.1093/nar/gkr1065

26. Petersen TN, Brunak S, von Heijne G, Nielsen H. SignalP 4.0: discriminating signal peptides from transmembrane regions. Nat Methods 2011; 8:785-786. PubMed http://dx.doi.org/10.1038/nmeth.1701

27. Krogh A, Larsson B, von Heijne G, Sonnhammer EL. Predicting transmembrane protein topology with a hidden Markov model: application to complete genomes. J Mol Biol 2001; 305:567580. PubMed http://dx.doi.org/10.1006/jmbi.2000.4315 